\title{
Effectiveness of Family Health Strategy on child's health indicators in São Paulo State
}

Sonia Isoyama Venancio 1

Tereza Etsuko da Costa Rosa 2

Maria Teresa Cera Sanches 3

Elza Yoshie Shigeno 4

José Maria Pacheco Souza 5

1,2,3,4 Instituto de Saúde. Secretaria de Estado da Saúde de São Paulo. Rua Santo Antônio 590. Bela Vista. São Paulo, SP, Brasil. CEP: 01.314-000. E-mail: soniav@isaude.sp.gov.br

5 Faculdade de Saúde Pública. Universidade de São Paulo. São Paulo, SP, Brasil.

\begin{abstract}
Objectives: to evaluate the effectiveness of Family Health Strategy (FHS) on child's health indicators in São Paulo State.

Methods: longitudinal ecological study involving all the towns in São Paulo State from 1998 to 2009. The outcomes were the coefficients of infant mortality and its components and the rate for pneumonia and diarrhea hospitalizations. The main independent variable was "FHS coverage"; the covariates considered the context of sociodemographic and the health system. Negative binomial regression models of fixed effects and STRATA 11.1 statistical program were used.

Results: FHS coverage above $50 \%$ showed a protective effect in relation to the postneonatal mortality (RR: 0.93; CI95\%: 0.87-1.00) and coverage up to 50\% (RR 0.88 CI 95\% 0.82-0.99) or above 50\% (RR: 0.87; CI95\%: 0.82-0.92) were protective factors for pneumonia hospitalizations.

Conclusions: the effectiveness of FHS on the outcomes related to child's health may vary according to local and regional contexts.
\end{abstract}

Key words Primary health care, Family health strategy, Child's health, Health assessment, Unified health system 


\section{Introduction}

The importance of Primary Health Care (PHC) is recognized for its ability to contribute to the achievement of better results in health conditions in different populations. ${ }^{1}$ The World Health Organization (WHO) directs its strengthens in all countries as a main strategy to reorganize the health systems to overcome the inequalities in access, cost reduction and achieve results in health policies of the world. ${ }^{2}$

In Brazil, PHS (called Primary Health Care-PC) is placed as a starting point to reorganize the Unified Health System (SUS) and according to the Ministry of Health (MH) is characterized by "a set of health actions that are guided by the principles of universality, accessibility, care coordination, bond and continuity, integrity, responsibility, humanization, equity and social participation". 3

The Family Health Strategy (FHS), the State policy and strategy prioritized by the Ministry of Health to organize PC in Brazil, has expanded at high speed since 1994 and in 2015 reached an estimated coverage of $67 \%$ of the Brazilian population. 4

Considering the significant social inequalities and the lack of public resources for financing the health sector in the country, the assessment becomes essential to establish the capacity of response on policies, programs and services in needs of health for the population. 5 Thus, in Brazil, the health assessment has been constituted as a policy, since health actions are to demand greater managerial competence, articulations and production of information. 6 In this scenario of demands are results, monitoring and assessment, it became necessary to establish the assessment with the fundamental purpose to give support to the decision-making processes, subsidizing the identification of the problems, redirecting actions and services, assessing the incorporation on new practices and measuring the impact of actions implemented by health services. ${ }^{7}$

In view of the investments that have been made for the expansion and consolidation of FHS, it is essential to carry out researches that assess the extent to which it is associated to changes in the health population. In this sense, the Ministry of Health created the Coordination to Monitor and Assess Primary Care, in the Department of Primary Care of the Secretary of Health Care, structured initiatives directed in monitoring and assessing actions and health services and the induction and management in studies and researches. ${ }^{8}$

In this context, several studies on FHS were developed in the country since 2005 , inserted into a project that sought to diagnose epidemiological pattern and organize services in 168 towns in the country with more than 100.000 inhabitants, which are pointed out as major challenges for the consolidation of FHS.9-14 Researches at national scope on the effectiveness of FHS were also conducted, indicating that sites with greater coverage on Family Health presented better results in the health indicators, in particularly infant mortality. 15,16

In São Paulo State verified scarcity in studies similar to those conducted at national level with a proposal to assess the impact of FHS on the health indicators. It is considered that there is particular interest in assessing the impact of FHS in this State, according to the low population coverage of the Strategy, which was around $39 \%$ in 2015, and below this was in other States. 4 Moreover, São Paulo State is characterized by the coexistence of two care models (FHS and PC guided by specialists and programmatic actions) in large areas of towns, especially those in larger size. 17

Thus, the objective of this study was to assess the effectiveness of FHS on child's health indicators in São Paulo State from 1998 to 2009 in a distinct reality in most States in the country.

\section{Methods}

This is a longitudinal ecological study, in which temporal series of several child's health indicators were analyzed in 645 towns in São Paulo State from 1998 to 2009.

A theoretical model was built on child mortality determinants, taking into consideration factors to which have been assigned to a declining trend in this indicator, a phenomenon that has been observed in Brazil more steeply from the 1980s. ${ }^{18}$ Studies on the infant mortality behavior indicate the importance of social and economic factors, the public policies of basic sanitation and nutrition, the fall of fertility and the expansion of primary care services, especially the programs directed to women and children's health. 16 To elaborate the theoretical model in this study, the most significant variables were selected taking in consideration the context of São Paulo State.

The following outcomes were considered, these data were extracted from the Mortality Information System (SIM) and the Information System on Live Births (SINASC): 1) Infant Mortality: the number of deaths less than 1 year of age in each town in 1998 to 2009 , taking as a reference, the number of live births in the towns in the same period; 2) Neonatal Mortality: the number of deaths up to 27 days of life 
in each town in 1998 to 2009 , taking as a reference the number of live births in the towns in the same period; 3) Post-Neonatal Mortality: number of deaths of 28 to 364 days in each town in 1998 to 2009 , taking as a reference the number of live births in the towns in the same period. Even as intermediaries outcomes two other indicators were included: hospital admissions for pneumonia and hospitalizations for diarrhea in children under one year of age, these data were extracted from the Hospital Information System (HIS). These indicators were selected because they have been included in the list of admissions for primary care sensitive conditions (PCSC), a concept developed in the late 1980s in the United States and incorporated by the Ministry of Health in 2008, in order to evaluate accessibility and effectiveness of primary care in health. 19

The main independent variable was FHS coverage, calculated by dividing the number of people enrolled in the Primary Care Information System (SIAB) according to the total number of the population of the town (IBGE), considering the following levels of coverage: zero or no coverage (reference category); low coverage (up to $50 \%$ ) and high coverage ( $\geq 50 \%)$.

The variables were grouped into three dimensions: 1) socioeconomic dimension, represented by the Index of Social Responsibility (IPRS), elaborated by Fundação SEADE20 with the goal of characterizing the towns in São Paulo according to the indicators of health, education and wealth. The towns are classified into five groups, group 1 as the one with the best performance in the indicators and group 5 as the worst. In this study, five categories were grouped into two: the low IPRS (reference category, considering the groups of towns with classification 3.4 and 5) and the high IPRS groups (1.2); 2) demographic dimension, considering the birth rate (expressed by the number of children born annually - Fundação SEADE per a thousand inhabitantsIBGE) and the population size of the towns, classified as $\leq 10,000$ inhabitants (reference category); > 10,000 and $\leq 50,000$ inhabitants; $>50,000$ and $\leq$ 100,000 and over 100,000 inhabitants and 3) the size of the health system, represented by the rate of cesarean section (\% of cesarean births in relation to the total number of deliveries, according to SINASC information); rate of ICU beds (number of ICU Infant beds in relation to the population of children under one year of age; the neonatal mortality model were considered only Neonatal ICU hospital beds (data provided by the State Secretary of Health in São Paulo- SES-SP); and the percentage of the population receiving supplementary health $(\%$ of people who have private health plans in relation to the total population of towns in the year according to the National Agency of Health Supplementary /ANS). All the models were adjusted for the variable "year" (1998 to 2009).

The outcomes constitutes on counting data, which are records of the frequent relative occurrence of certain events in successive intervals of time. Thus, the data were analyzed using panel data models or longitudinal data models, which multiple units $(n>1)$ have repeated observations. 16

A negative binomial regression models with fixed effects was used, which have been widely used in studies to assess the effectiveness of FHS on various outcomes. 15,16,21,22 The reasons to use such models are: (a) the fact that the response of the variable consists of repeated measurements; b) The possibility of each analysis unit have its intercept, being as its own control, which allows to adjust for the non-measured variables and does not vary over time and c) the possibility of modeling directly the number of events and not the rates, which may vary depending on the changes in the numerator or the denominator. For the choice between negative binomial regression models of fixed effect (fixed effect $\mathrm{FE}$ ), or random (random effect - RE), Hausman test was used. 23 The analyzes were carried out by using a statistic program, STATA 11.

\section{Results}

The infant mortality rate showed a decrease in the State with reduction of approximately $30 \%$ in the study period. In 1998, the rate was 18.67 and in 2009 reached to 12.48 per thousand live births. In relation to the components, there are a greater burden of neonatal mortality, which showed a reduction of 12.61 to 8.68 per thousand live births; the postneonatal mortality began the period with the lowest rate of 6.07 and dropped to 3.81 live births in 2009 (Figure 1). In relation to hospitalizations for pneumonia, the indicator showed variations, but there was a reduction of $11 \%$ on the coefficient when comparing to the initial rate (4.71) at the end of the period (4.20). The hospitalizations rates, due to diarrhea, are inferior to those of pneumonia and suffered a $30 \%$ reduction in the period from 0.73 in 1998 to 0.5 in 2009 (Figure 2).

The FHS coverage showed an increasing trend over the entire period reaching $28.1 \%$ in 2009 , but this increase was more intense in smaller towns (Figure 3).

The behavior of the covariates are summarized as followed: The classification of the towns in rela- 
tion to the groups of IPRS did not suffer any expressive alterations over the period; the birth rate for all São Paulo towns presented a reduction of approximately $25 \%$; there was an increasing trend in the rates of cesarean section going from $47 \%$ to $57 \%$; the availability of Infant ICU hospital beds increased in absolute numbers, 15 times, and the Neonatal ICU, 30 times, during the study period; the population covered by health plans increased from $38 \%$ in 2000 to just a little over $40 \%$ in 2009 . The results of negative binomial regression models with fixed effects for the outcomes related to infant, neonatal and post-neonatal mortality are shown in Table 1 .

In relation to infant mortality, in the bivariate analysis, the relative gross risks showed a protective effect on FHS in both groups of coverage $(<50 \%$ and $>50 \%$ ). However, after adjusting to other factors, the relative risks of infant mortality in the groups were up to $50 \%$ coverage of FHS and $50 \%$ or more, compared to the absence of FHS, are less than 1 and indicate a protective effect, but did not have statistical significant association with the outcome. The same occurred in relation to the socioeconomic context: there was a protective effect of high IPRS, with a loss on the statistical significance after the adjustment, compared to the group of low IPRS, which are classified towns with low wealth. The coverage on supplementary health, birth rate, cesarean section rate, infant ICU rate and the population size did not show any statistical significant association with the outcome. The decrease trend in infant mortality was confirmed with a statistical sugnificance of reduction over the years.

The neonatal mortality model showed that the variables analyzed have similar behavior to the infant mortality model. A reduction in neonatal mortality was also observed as a possible protective effect of FHS coverage, however only in the nonadjusted analysis. As so, there were no association with the outcome IPRS variables, birth rate, cesarean section rate, supplementary health coverage, population size and the availability of hospital beds in the neonatal ICU.

The analysis of post-neonatal mortality showed a protective effect of greater FHS coverage in relation to the outcome with effect like "dose-response" in a gross analysis and after adjusting for the other variables in the model, the association remains close to the statistical significance. In the towns group with FHS coverage less than or equal to $50 \%$ there was a reduction of $3.9 \%$ in the risk of post-neonatal mortality, although without statistical significance (RR: 0.96; CI95\%: 0.92-1.00), and in the group with more than $50 \%$ this reduction was of $7 \%$ (RR: 0.93 ; CI95\%: 0.86-0.99), in comparison to the absence of
FHS. There was no influence on IPRS, the population with health plans coverage, the hospital beds at pediatric ICU or population size. In the years after 1998 , there was a lower risk of mortality, statistically significant.

The analysis of the influence of FHS on hospitalizations for pneumonia and diarrhea is presented in Table 2.

In relation to hospitalizations due to diarrhea in children under one year of age, there was a protective effect of FHS in the coverage group $\leq 50 \%$ and the highest outcome risk in the greater coverage group in the gross analysis. After adjusting the other variables both groups are to set up protection in comparison to the towns with zero coverage, however the association is not statistically significant. The best group of IPRS and the increased coverage of health supplement showed statistical significant associations with the outcome, pointing protective effect on the same. The towns of greater population size also conferred protection in relation to hospitalizations due to diarrhea, when compared to towns with up to 10,000 inhabitants, having a $74.7 \%$ reduction in the towns between 10,000 and 50,000 inhabitants and more than $94.8 \%$ in towns with more than 50,000 inhabitants.

Positive Influence of FHS coverage, statistically significant, could be verified in relation to hospitalizations for pneumonia. In the towns with coverage $\leq 50 \%$, there was a statistically significant reduction of $11.9 \%$ in the risk of hospitalizations for pneumonia, and the larger group coverage, the reduction increased to $12.7 \%$. The towns with high IPRS had a protective effect in relation to the outcome as was observed, as well as those with greater coverage of health care plans and a greater population size, and these associations were statistically significant.

\section{Discussion}

This study showed that in the São Paulo State FHS has had a positive impact on the reduction of postneonatal mortality and hospitalizations for pneumonia in children under one year of age, however there has been no verification on the positive impact of infant and neonatal mortality and hospitalizations for diarrhea.

These results differ from those published by some authors by examining the national context. Macinko et al. 15 when analyzing the data from all the Brazilian States from 1990 to 2002, found an increase of $10 \%$ coverage of the Program associated to a decline of $4.5 \%$ in the infant mortality rates, after the control of other determinants. 


\section{Figure 1}

Evolution of the infant mortality rate and components in neonatal and post-neonatal mortality in São Paulo State, 19982009.

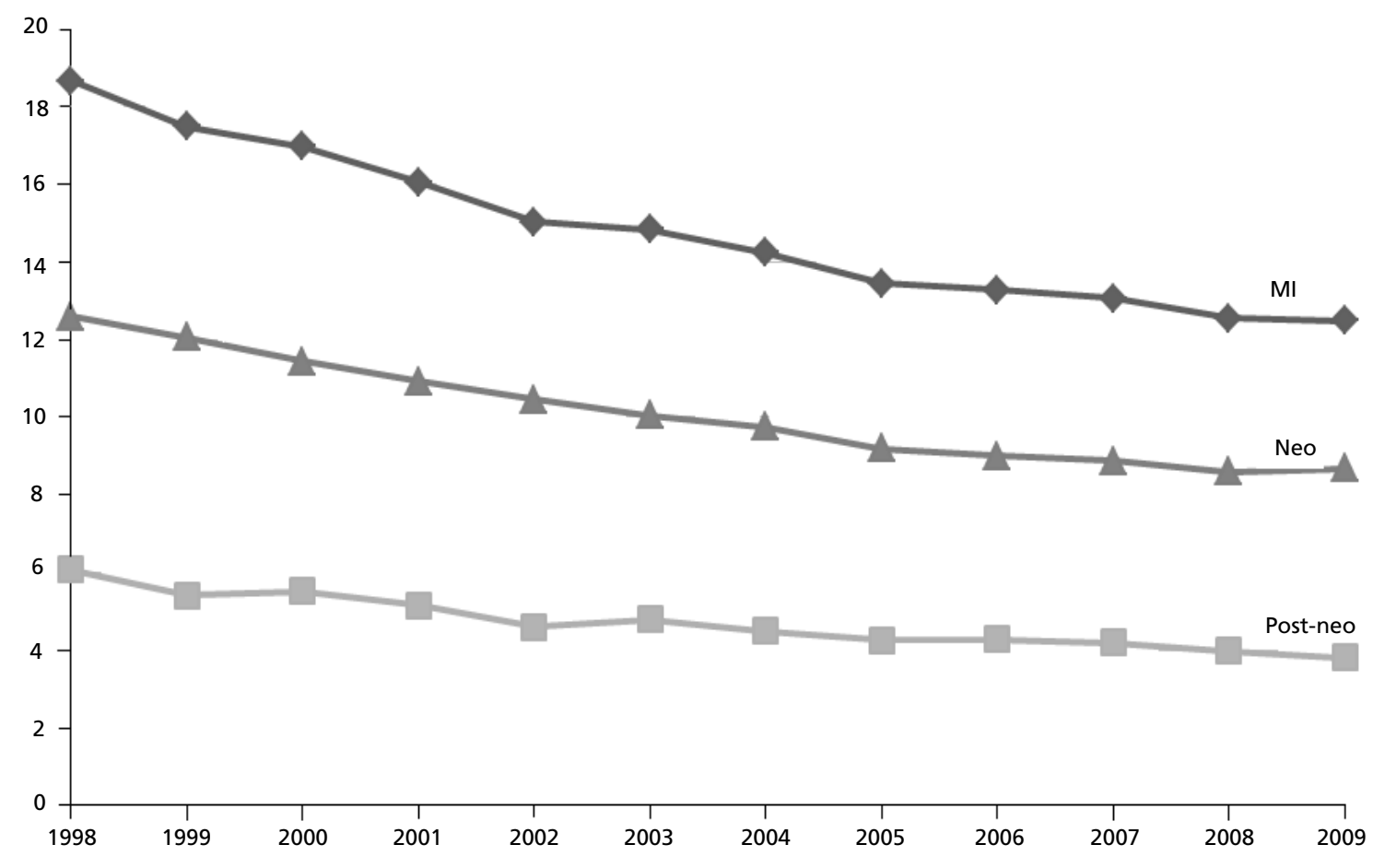

$\mathrm{Ml}=$ infant mortality; $\mathrm{Neo}=$ neonatal components; Post-neo= components post-neonatal mortality.

\section{Figure 2}

Evolution of hospitalization rates due to diarrhea and pneumonia in children under one year of age in São Paulo State, 19982009.

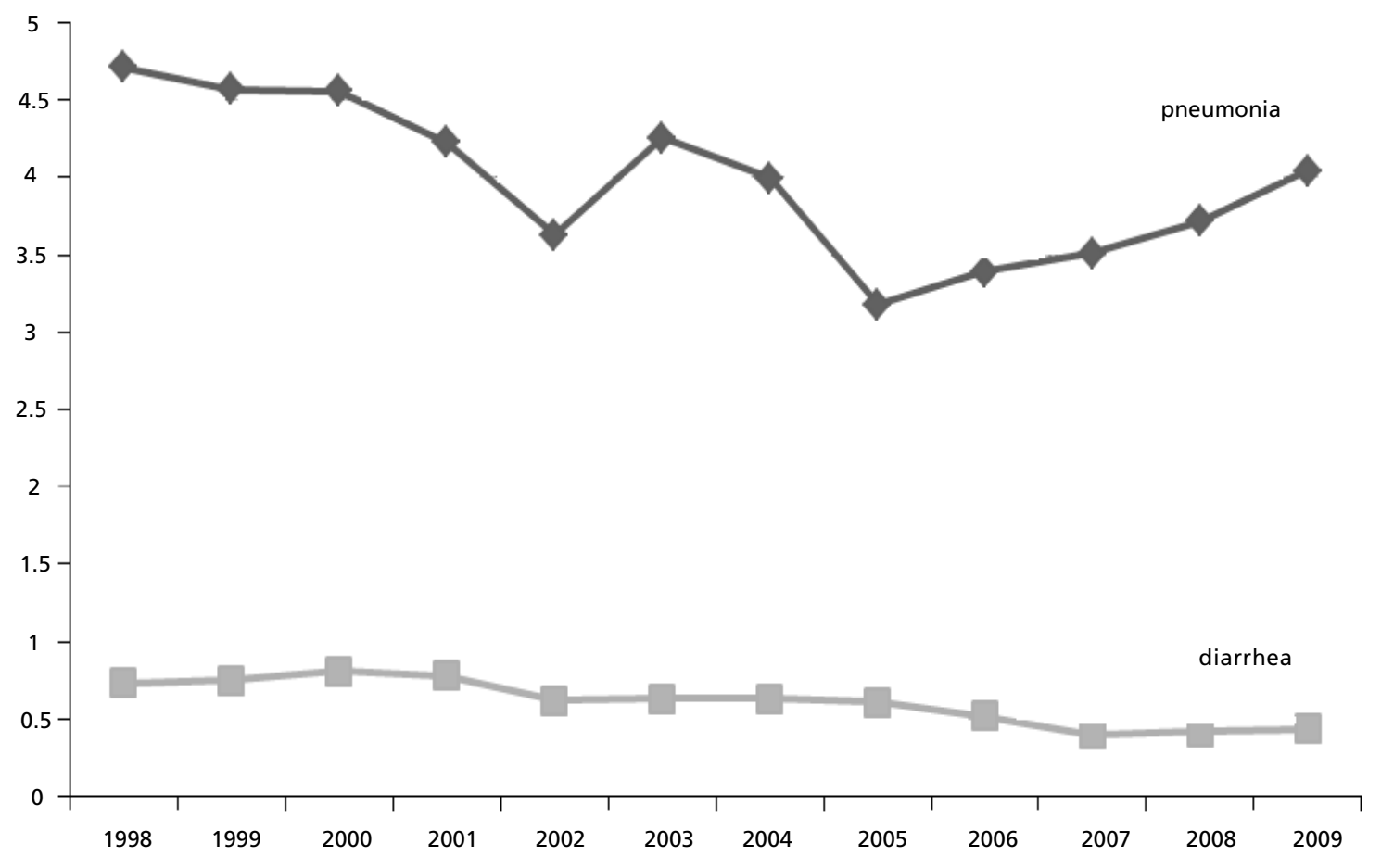




\section{Figure 3}

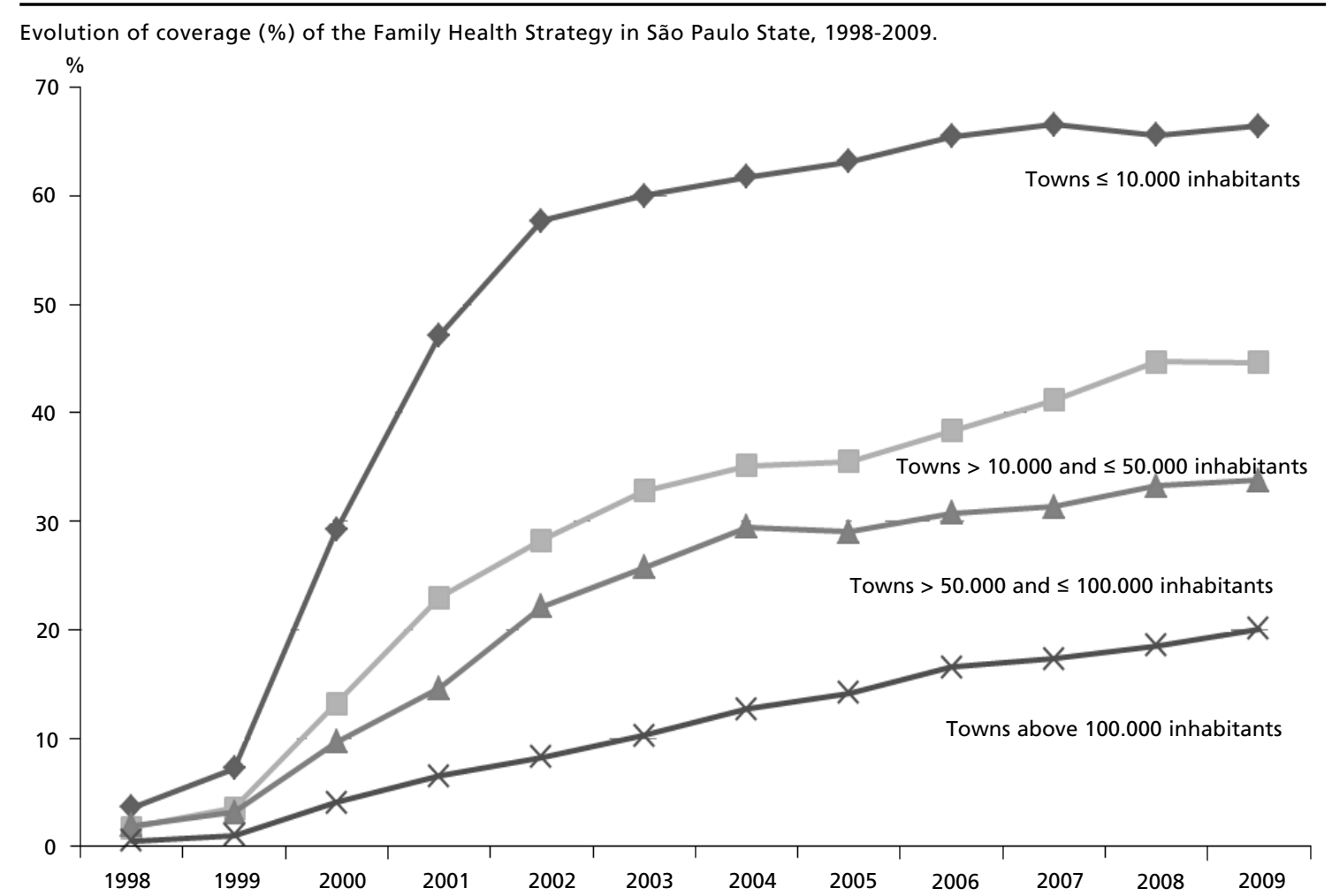

Table 1

Regression models in relation between Family Health Strategy coverage and infant mortality in the towns of São Paulo, 1998 to 2009.

\begin{tabular}{|c|c|c|c|c|c|c|}
\hline & \multicolumn{2}{|c|}{ Infant mortality rate } & \multicolumn{2}{|c|}{ Neonatal Mortality } & \multicolumn{2}{|c|}{ Post-Neonatal Mortality } \\
\hline & $\begin{array}{c}\text { Gross RR } \\
(\mathrm{Cl} 95 \%)\end{array}$ & $\begin{array}{l}\text { RR adjusted } \\
\text { (CI 95\%) }\end{array}$ & $\begin{array}{l}\text { Gross RR } \\
(\mathrm{Cl} 95 \%)\end{array}$ & $\begin{array}{l}\text { RR adjusted } \\
\text { (CI 95\%) }\end{array}$ & $\begin{array}{c}\text { Gross RR } \\
(\mathrm{Cl} 95 \%)\end{array}$ & $\begin{array}{l}\text { RR adjusted } \\
\text { (CI95\%) }\end{array}$ \\
\hline \multicolumn{7}{|l|}{ FHS coverage } \\
\hline None & 1.00 & 1.00 & 1.000 & 1.00 & 1.00 & 1.00 \\
\hline \multirow[t]{2}{*}{$\leq 50 \%$} & 0.81 & 0.98 & 0.824 & 0.99 & 0.80 & 0.96 \\
\hline & $(0.79-0.83)$ & $(0.95-1.00)$ & $(0.802-0.846)$ & $(0.96-1.01)$ & $(0.77-0.83)$ & $(0.92-1.00)$ \\
\hline \multirow[t]{2}{*}{$>50 \%$} & 0.75 & 0.97 & 0.766 & 1.00 & 0.71 & 0.93 \\
\hline & $(0.72-0.78)$ & $(0.93-1.01)$ & $(0.731-0.803)$ & $(0.95-1.05)$ & $(0.66-0.76)$ & $(0.86-0.99)$ \\
\hline \multicolumn{7}{|l|}{ IPRS } \\
\hline $3 / 4 / 5$ & & 1.00 & & 1.00 & & 1.00 \\
\hline \multirow[t]{2}{*}{$1 / 2$} & & 0.99 & & 0.98 & & 1.01 \\
\hline & & $(0.94-1.04)$ & & $(0.92-1.04)$ & & $(0.92-1.10)$ \\
\hline \multirow[t]{2}{*}{ Birth rate } & & 0.998 & & 1.00 & & 0.99 \\
\hline & & $(0.99-1.00)$ & & $(0.99-1.00)$ & & $(0.98-1.00)$ \\
\hline \multirow[t]{2}{*}{ Cesarean section rate } & & 0.99 & & 0.99 & & - \\
\hline & & $(0.99-1.00)$ & & $(0.99-1.00)$ & & \\
\hline \multirow[t]{2}{*}{ ICU hospital beds rate } & & 1.00 & & 1.00 & & 1.00 \\
\hline & & $(0.99-1.00)$ & & $(0.99-1.00)^{*}$ & & $(0.99-1.00)$ \\
\hline \multirow[t]{2}{*}{ Health plans coverage } & & 1.00 & & 1.00 & & 0.99 \\
\hline & & $(0.99-1.00)$ & & $(0.99-1.00)$ & & $(0.99-1.00)$ \\
\hline
\end{tabular}

continue

FHS= Family Health Strategy; IPRS= São Paulo Index of Social Responsibility; ICU = Intensive Care Unit;

* ICU = Neonatal Intensive Care Unit; RR= Relative Risk; Cl= Confidence Interval. Likelihood-ratio test $=0,000$. 
Regression models in relation between Family Health Strategy coverage and infant mortality in the towns of São Paulo, 1998 to 2009.

\begin{tabular}{|c|c|c|c|c|c|c|}
\hline & \multicolumn{2}{|c|}{ Infant mortality rate } & \multicolumn{2}{|c|}{ Neonatal Mortality } & \multicolumn{2}{|c|}{ Post-Neonatal Mortality } \\
\hline & $\begin{array}{c}\text { Gross RR } \\
(\mathrm{Cl} 95 \%)\end{array}$ & $\begin{array}{l}\text { RR adjusted } \\
\text { (Cl 95\%) }\end{array}$ & $\begin{array}{l}\text { Gross RR } \\
(\mathrm{Cl} 95 \%)\end{array}$ & $\begin{array}{l}\text { RR adjusted } \\
\text { (CI 95\%) }\end{array}$ & $\begin{array}{l}\text { Gross RR } \\
(\mathrm{Cl} 95 \%)\end{array}$ & $\begin{array}{l}\text { RR adjusted } \\
\text { (Cl } 95 \%)\end{array}$ \\
\hline \multicolumn{7}{|l|}{ Population size } \\
\hline \multicolumn{7}{|l|}{ (inhab) } \\
\hline$\leq 10.000$ & & 1.00 & & 1.00 & & 1.00 \\
\hline \multirow[t]{2}{*}{$>10.000 \leq 50.000$} & & 0.93 & & 0.89 & & 0.94 \\
\hline & & $(0.79-1.10)$ & & $(0.73-1.08)$ & & $(0.70-1.25)$ \\
\hline \multirow{2}{*}{$\begin{array}{l}>50.000 \\
\leq 100.000\end{array}$} & & 0.91 & & 0.85 & & 0.92 \\
\hline & & $(0.75-1.09)$ & & $(0.68-1.07)$ & & $(0.65-1.28)$ \\
\hline \multirow[t]{2}{*}{$>100.000$} & & 0.92 & & 0.85 & & 0.95 \\
\hline & & $(0.76-1.11)$ & & $(0.67-1.07)$ & & $(0.68-1.34)$ \\
\hline \multicolumn{7}{|l|}{ Year } \\
\hline 1998 & & 1.00 & & 1.00 & & 1.00 \\
\hline \multirow[t]{2}{*}{1999} & & 0.93 & & 0.95 & & 0.88 \\
\hline & & $(0.91-0.95)$ & & $(0.92-0.98)$ & & $(0.85-0.92)$ \\
\hline \multirow[t]{2}{*}{2000} & & 0.90 & & 0.90 & & 0.89 \\
\hline & & $(0.87-0.92)$ & & $(0.87-0.93)$ & & $(0.85-0.94)$ \\
\hline \multirow[t]{2}{*}{2001} & & 0.85 & & 0.87 & & 0.82 \\
\hline & & $(0.83-0.88)$ & & $(0.83-0.91)$ & & $(0.78-0.87)$ \\
\hline \multirow[t]{2}{*}{2002} & & 0.80 & & 0.83 & & 0.73 \\
\hline & & $(0.77-0.83)$ & & $(0.80-0.87)$ & & $(0.68-0.78)$ \\
\hline \multirow[t]{2}{*}{2003} & & 0.80 & & 0.80 & & 0.78 \\
\hline & & $(0.76-0.83)$ & & $(0.76-0.85)$ & & $(0.72-0.85)$ \\
\hline \multirow[t]{2}{*}{2004} & & 0.76 & & 0.78 & & 0.72 \\
\hline & & $(0.73-0.79)$ & & $(0.74-0.82)$ & & $(0.67-0.77)$ \\
\hline \multirow[t]{2}{*}{2005} & & 0.71 & & 0.74 & & 0.67 \\
\hline & & $(0.68-0.75)$ & & $(0.70-0.78)$ & & $(0.62-0.72)$ \\
\hline \multirow[t]{2}{*}{2006} & & 0.70 & & 0.72 & & 0.67 \\
\hline & & $(0.67-0.74)$ & & $(0.68-0.77)$ & & $(0.62-0.73)$ \\
\hline \multirow[t]{2}{*}{2007} & & 0.699 & & 0.71 & & 0.66 \\
\hline & & $(0.66-0.73)$ & & $(0.67-0.76)$ & & $(0.61-0.72)$ \\
\hline \multirow[t]{2}{*}{2008} & & 0.66 & & 0.69 & & 0.64 \\
\hline & & $(0.63-0.70)$ & & $(0.64-0.74)$ & & $(0.59-0.71)$ \\
\hline \multirow[t]{2}{*}{2009} & & 0.66 & & 0.70 & & 0.60 \\
\hline & & $(0.63-0.70)$ & & $(0.66-0.74)$ & & $(0.55-0.65)$ \\
\hline
\end{tabular}

FHS= Family Health Strategy; IPRS= São Paulo Index of Social Responsibility; ICU = Intensive Care Unit

* ICU = Neonatal Intensive Care Unit; RR= Relative Risk; $\mathrm{Cl}=$ Confidence Interval. Likelihood-ratio test $=0,000$. 
Regression models in relation between Family Health Strategy coverage and hospitalizations due to diarrhea and pneumonia in towns in São Paulo State, 1998 to 2009.

\begin{tabular}{|c|c|c|c|c|}
\hline & \multicolumn{2}{|c|}{ Hospitalization due to diarrhea } & \multicolumn{2}{|c|}{ Hospitalization due to pneumonia } \\
\hline & $\begin{array}{c}\text { Gross RR } \\
(\mathrm{Cl} \mathrm{95 \% )}\end{array}$ & $\begin{array}{l}\text { RR adjusted } \\
(\mathrm{Cl} 95 \%)\end{array}$ & $\begin{array}{l}\text { Gross RR } \\
(\mathrm{Cl} 95 \%)\end{array}$ & $\begin{array}{l}\text { RR adjusted } \\
\text { (CI 95\%) }\end{array}$ \\
\hline \multicolumn{5}{|l|}{ FHS coverage } \\
\hline None & 1.00 & 1.00 & 1.00 & 1.00 \\
\hline \multirow{2}{*}{$\leq 50 \%$} & 0.68 & 0.94 & 0.66 & 0.88 \\
\hline & $(0.64-0.73)$ & $(0.87-1.03)$ & $(0.64-0.68)$ & $(0.82-0.92)$ \\
\hline \multirow[t]{2}{*}{$>50 \%$} & 1.19 & 0.99 & 0.90 & 0.87 \\
\hline & $(1.10-1.30)$ & $(0.89-1.09)$ & $(0.85-0.94)$ & $(0.82-0.92)$ \\
\hline \multicolumn{5}{|l|}{ IPRS } \\
\hline $3 / 4 / 5$ & & 1.00 & & 1.00 \\
\hline \multirow[t]{2}{*}{$1 / 2$} & & 0.71 & & 0.66 \\
\hline & & $(0.62-0.81)$ & & $(0.61-0.71)$ \\
\hline \multirow[t]{2}{*}{ Health plan coverage } & & 0.99 & & 0.98 \\
\hline & & $(0.99-0.99)$ & & $(0.98-0.99)$ \\
\hline \multirow[t]{2}{*}{ ICU hospital beds rate } & & 0.99 & & 1.00 \\
\hline & & $(0.99-1.00)$ & & $(0.99-1.00)$ \\
\hline \multicolumn{5}{|l|}{ Population size (inhab) } \\
\hline$\leq 10.000$ & & 1.00 & & 1.00 \\
\hline \multirow[t]{2}{*}{$>10.000 \leq 50.000$} & & 0.25 & & 0.40 \\
\hline & & $(0.21-0.29)$ & & $(0.37-0.44)$ \\
\hline \multirow[t]{2}{*}{$>50.000 \leq 100.000$} & & 0.05 & & 0.12 \\
\hline & & $(0.04-0.06)$ & & $(0.10-0.13)$ \\
\hline \multirow[t]{2}{*}{$>100.000$} & & 0.04 & & 0.09 \\
\hline & & $(0.03-0.05)$ & & $(-0.08-0.10)$ \\
\hline \multicolumn{5}{|l|}{ Year } \\
\hline 1998 & & 1.00 & & 1.00 \\
\hline \multirow[t]{2}{*}{1999} & & 1.07 & & 0.93 \\
\hline & & $(0.96-1.19)$ & & $(0.88-0.98)$ \\
\hline \multirow[t]{2}{*}{2000} & & 1.25 & & 1.01 \\
\hline & & $(1.12-1.39)$ & & $(0.95-1.07)$ \\
\hline \multirow[t]{2}{*}{2001} & & 1.25 & & 1.02 \\
\hline & & $(1.11-1.39)$ & & $(0.96-1.08)$ \\
\hline \multirow[t]{2}{*}{2002} & & 1.06 & & 0.85 \\
\hline & & $(0.95-1.19)$ & & $(0.79-0.90)$ \\
\hline \multirow[t]{2}{*}{2003} & & 1.01 & & 0.86 \\
\hline & & $(0.89-1.15)$ & & $(0.80-0.91)$ \\
\hline \multirow[t]{2}{*}{2004} & & 0.99 & & 0.88 \\
\hline & & $(0.88-1.12)$ & & $(0.82-0.93)$ \\
\hline \multirow[t]{2}{*}{2005} & & 1.03 & & 0.71 \\
\hline & & $(0.92-1.16)$ & & $(0.67-0.76)$ \\
\hline \multirow[t]{2}{*}{2006} & & 0.94 & & 0.78 \\
\hline & & $(0.83-1.06)$ & & $(0.73-0.83)$ \\
\hline \multirow[t]{2}{*}{2007} & & 0.76 & & 0.78 \\
\hline & & $(0.67-0.87)$ & & $(0.73-0.83)$ \\
\hline 2008 & & 0.80 & & 0.79 \\
\hline & & $(0.70-0.92)$ & & $(0.74-0.85)$ \\
\hline 2009 & & 0.88 & & 0.92 \\
\hline & & $(0.77-1.00)$ & & $(0.86-0.99)$ \\
\hline
\end{tabular}

FHS= Family Health Strategy; IPRS=São Paulo Index of Social Responsibility; RR= Relative Risk; $\mathrm{Cl}=$ Confidence Interval. Likelihood-ratio test $=0,000$. 
Aquino et al.16 studied the impact of FHP coverage on child mortality in 771 of the 5561 Brazilian towns and observed a negative association and statistically significant difference between the coverage of the Program and the infant mortality rates. After the control of the confounding variables, the reductions in child mortality rates were $13 \%$, $16 \%$ and $22 \%$ for 3 increasing levels of the Program coverage. They found that the impact of the FHP was higher in towns with higher infant mortality rates and lower Human Development Index (HDI) rates. ${ }^{16}$

Rasella et al. ${ }^{21}$ assessed the data on mortality in children under 5 years old in 2601 Brazilian towns from 2000 to 2005 and found a statistically significant negative association between the levels of FHP coverage and infant mortality rates. The reductions in the rates ranged from $4 \%$ to $13 \%$, being higher in towns with coverage greater than $70 \%$.

Some hypotheses can be raised in an attempt to explain the differences between the results of studies of a national scope and the results of this study. First, one must take into consideration that the rates of infant mortality in São Paulo State differ significantly from the national rates: while the coefficient was 12.5 per 1000 live births in 2009 , the infant mortality rate in Brazil was 22.5 per 1000 live births in the same year. This difference may have influenced the analysis on the effect of FHS in São Paulo, once verified that the impact of the Strategy is higher in places where these rates are higher. 16

One aspect that deserves attention is the fact that FHS coverage is lower in the context of São Paulo: while in Brazil about $50 \%$ of the population was already covered by FHS in 20084 in São Paulo State the coverage reached in the same year just over a third of the population. This is another factor that may have led to differences in relation to the effectiveness of FHS found in this study, once the greater impact of the Strategy is found in places with greater coverage. ${ }^{21}$

Another point which can be raised relates to the existence, in São Paulo State, a vast network of primary care services prior to the implementation of FHS. Souza et al. ${ }^{17}$ showed on the Agenda of the Manager of Health in São Paulo State, the main milestones of the trajectory of Primary Health Care in São Paulo State. The authors drew attention to the fact that during the period of 1960 to 1990 , São Paulo could be considered the State that advanced more in the constitution of networks of Health Centers, reinforced by the Alma-Ata Movement in 1978. It is in this scenario verified that in the $1990 \mathrm{~s}$, the implementation of FHP with a proposal substantially different. This new model has been occupying the place of the previous model in the health program adopted by Health Centers in a more expressive way in small towns and in regions where Health Centers did not exist or were unstructured. 17 This study found that the greatest coverage of FHS are in towns with less than 10,000 inhabitants. In metropolitan areas and in most medium/large towns, due to the historical features, there are currently two models of care, although in larger towns, FHS coverage is lower than $10 \%$.

In relation to hospitalizations due to diarrhea, there was no protective effect of greater coverage in FHS. The decline in the hospitalization rates were influenced by IPRS and the population size and could be associated to factors not considered in the analysis, such as the introduction of the vaccine for rotavirus in 2006.24 The positive impact on FHS for hospitalizations for pneumonia was positive and for this outcome the dose-response effect, in other words, the higher FHS coverage is, lower the risk of hospitalization. This data confirms Dourado et al.22 findings which found a greater reduction of the PCSC in the States with greater coverage of FHS. In the same way, Carvalho et al.25 analyzing children's hospitalizations of sensitive conditions for primary care in Pernambuco in the similar period of this study (1999 to 2009), there was an increased coverage of FHS and had a protective effect against PCSC. It is interesting to observe that although the hospitalizations presented a trend of decreasing during the period, this occurred more frequently in small towns, the example identified by Souza e Costa26 in Rio Grande do Sul attributed this phenomenon to the Law of Roemer, according to which the health services have the capacity to generate their own demand supporting hospitalizations to justify hospital beds at any determined time.

The advantages have been pointed out by several authors in the use of the methodology adopted in this study, such as the ease of working with secondary data, the advances in the availability of the data bases, the appreciation of theoretical and empirical contextual variables in an explanatory models of the health phenomena and the fact that ecological studies constitute in one of the basic types of design of the epidemiological study apprehension of the determinants of the health and the sickness of the population, as for the implementation of health policies. Emphasizing the use of panel models for longitudinal data allows us to expand the number of observations and analyze temporal series for each town, which allows to control non-measured characteristics which will not vary with time and can affect the outcomes. 13

Some limitations of this study should be identified. The construction of the theoretical models 
presupposes the availability of information in the databases of a secondary data and the coverage of FHS, the main independent variable in this study does not allow a detailed analysis of the effect of different care models existing in São Paulo State. In addition to this, the relationship between FHS coverage and the health indicators were assessed in 1998 to 2009 , a period in which there was a further expansion of the Strategy in the State, however it is possible that the expansion of FHS coverage in recent years could modify the results presented in this study.

This design was also not possible to make inferences about the quality of care in FHS, assuming the coverage as an indicator of deployment of FHS. However, it is assumed that the absence of effect of FHS in several health indicators may also reflect problems in relation to the quality of care. A study conducted in 62 towns in São Paulo State with more than 100,000 inhabitants reinforces this idea, once identified, through interviews with $\mathrm{AB}$ users, a general index of satisfaction of $50 \%$, which qualifies as little satisfactory. 9 Rodrigues-Bastos et al. 27 discuss the lack of association between the reduction of PCSC and increased coverage of FHS in Minas Gerais from 2000 to 2010 , indicating that the imple-

\section{References}

1. World Health Organization. World Health Report 2008 Primary Health Care: Now More Than Ever. Geneva, Switzerland; 2008

2. Chan M. Primary health care as a route to health security. Lancet. 2009; 373: 1586-7.

3. Brasil. Ministério da Saúde. Secretaria de Atenção à Saúde Departamento de Atenção Básica. Política Nacional de Atenção Básica / Ministério da Saúde. Secretaria de Atenção à Saúde. Departamento de Atenção Básica. Brasília, DF; 2012.

4. Brasil. Ministério da Saúde. Secretaria da Atenção Básica. Departamento de Atenção Básica. [acesso em 28 dez 2015]. Disponível em: http://dab.saude.gov.br/portaldab/ historico_cobertura_sf.php.

5. Hartz ZMA, Vieira-da-Silva LM, organizadores. Avaliação em saúde: dos modelos teóricos à prática na avaliação de programas e sistemas de saúde. Salvador: EDUFBA; 2005.

6. Pinto-Junior EP, Cavalcante JLM, Sousa RA, Morais APP, Silva MGC. Análise da produção científica sobre avaliação, no contexto da saúde da família, em periódicos brasileiros. Saúde Debate. 2015; 39: 268-78.

7. Brasil. Ministério da Saúde. Secretaria de Atenção à Saúde. Avaliação na atenção básica em saúde: caminhos da institucionalização. Brasília, DF; 2005.

8. Bodstein R, Feliciano K, Hortale VA, Leal MC. Estudos de Linha de Base do Projeto de Expansão e Consolidação da Saúde da Família (ELB/Proesf): considerações sobre seu acompanhamento. Ciênc Saúde Coletiva. 2006; 11: 725-31. mentation of FHS may have contributed to broaden the coverage of primary care and for the organization of a health care model that adopted the family health as the entrance door to the system, but that possibly does not corresponds to an improvement in the level of organization and practices of these services, not reaching any expected resolution.

The future of FHS, its expansion to the urban centers and its effective integration to secondary and tertiary levels of care require a continuous engagement of health care providers, in addition to financial, technical and intellectual investment which ultimately will depend on political support. 28

This can be concluded that the effectiveness of FHS on the outcomes related to child's health may vary according to local contexts and regional authorities, which must be taken into account when formulating strategies for the improvement in the quality of $\mathrm{AB}$ and the child's health indicators. It is believed that this study has contributed to an impact analysis of FHS on child's health indicators in all towns in the State and it is expected that the results may can help managers and health professionals in strengthening the $\mathrm{AB}$ in the Unified Health System (SUS) in São Paulo.
9. Ibãnez N, Rocha JSY, Castro PC, Ribeiro MCSA, Forster AC, Novaes MHD, Viana ALA. Avaliação do desempenho da atenção básica no Estado de São Paulo. Ciênc Saúde Coletiva. 2006; 11: 683-703.

10. Roncalli AG, Lima KC. Impacto do Programa Saúde da Família sobre indicadores de saúde da criança em municípios de grande porte da região Nordeste do Brasil. Ciênc Saúde Coletiva. 2006; 11: 713-24.

11. Viana ALA, Rocha JSY, Elias PE, Ibañez N, Novaes MHD. Modelos de atenção básica nos grandes municípios paulistas: efetividade, eficácia, sustentabilidade e governabilidade. Ciênc Saúde Coletiva. 2006; 11: 577-606.

12. Szwarcwald CL; Mendonça MHM; Andrade CLT. Indicadores de atenção básica em quatro municípios do estado do Rio de Janeiro, 2005: resultados de inquérito domiciliar de base populacional. Ciênc Saúde Coletiva. 2006; 11: 643-55

13. Facchini LA, Piccini RX, Tomasi E, Thumé E, Silveira DS, Siqueira FV, Rodrigues MA. Desempenho do PSF no Sul e no Nordeste do Brasil: avaliação institucional e epidemiológica da Atenção Básica à Saúde. Cienc Saúde Coletiva. 2006; 11: 669-81.

14. Elias PE, Ferreira CW, Alves MCG, Cohn A, Kishima V, Escrivão Junior A, Gomes A, Bousquat A. Atenção Básica em Saúde: comparação entre PSF e UBS por estrato de exclusão social no município de São Paulo. Ciênc Saúde Coletiva. 2006; 11: 633-41. 
15. Macinko J, Guanais FC, Souza MFM. Evaluation of impact $f$ the Family Health Program on infant mortality in Brazil, 1990-2002. J. Epidemiol Community Health. 2006; 60: 1319

16. Aquino R, Oliveira NF, Barreto ML: Impact of the Family Health Program on Infant Mortality in Brazilian Municipalities. Am J Public Health. 2009; 99: 87-93.

17. Souza RR, Campagnoni M, Azevedo CN. Agenda do gestor municipal de saúde: organizando o sistema a partir da atenção básica. São Paulo: Secretaria de Estado da Saúde de São Paulo, 2009.

18. Victora CG, Aquino EML, Leal MC, Monteiro CA, Barros FC, Szwarcwald CL. Maternal and child health in Brazil: progress and challenges. Lancet. 2011; 377: 1863-76.

19. Alfradique ME, Bonolo PF, Dourado I, Lima-Costa MF, Macinko J, Mendonça CS, Oliveira VB, Sampaio LFR, Simoni C, Turci MA. Internações por condições sensíveis à atenção primária: a construção da lista brasileira como ferramenta para medir o desempenho do sistema de saúde (Projeto ICSAP - Brasil). Cad Saúde Pública. 2009; 25: 1337-49.

20. Fundação Seade. IPRS versão 2010. Metodologia. [acesso em 8 ago 2016]. Disponível em: http://indicesilp.al.sp.gov.br/view/pdf/ipvs/estado.pdf

21. Rasella D. Aquino R; Barreto ML. Impact of the Family Health Program on the quality of vital information and reduction of child unattended deaths in Brazil: an ecological longitudinal study. BMC Public Health. 2010; 10 380 .

Received on April 18, 2016

Final version presented on August 11, 2016

Approved on September 1, 2016
22. Dourado I, Oliveira VB, Aquino R, Bonolo P, Lima-Costa MF, Medina MG, Mota E, Turci MA, Macinko J. Trends in Primary Health Care Care-sensitive Conditions In Brazil: the role of Family Health Program (Project ICSAP-Brazil). Medical Care. 2011; 49: 577-84.

23. Frees WE. Longitudinal and panel data. Cambridge, United Kingdom: Cambridge University Press; 2004.

24. São Paulo. Secretaria de Estado da Saúde. Informe técnico vacina contra rotavírus. São Paulo: Secretaria de Estado da Saúde de São Paulo, 2006. [acesso em 8 ago 2016]. Disponível em: http://www.saude.sp.gov.br/cve-centro-devigilancia-epidemiologica-prof.-alexandre-vranjac/areasde-vigilancia/imunizacao/documentos-tecnicos

25. Carvalho SC, Mota EDI, Aquino R, Teles C, Medina MG Hospitalizations of children due to primary health care sensitive conditions in Pernambuco State, Northeast Brazil. Cad Saúde Pública. 2015; 31: 744-54.

26. Souza LL, Costa JSD. Internações por condições sensíveis à atenção primária nas coordenadorias de saúde no RS. Rev Saúde Pública. 2011; 45 (4): 765-72.

27. Rodrigues-Bastos RM, Campos EMS, Ribeiro LC, Bastos Filho MG, Bustamante-Teixeira MT. Hospitalizations for ambulatory care-sensitive conditions, Minas Gerais, Southeastern Brazil, 2000 and 2010. Rev Saúde Pública. 2014; 48: 958-67.

28. Macinko J; Harris MJ. Brazil's Family Health Strategy Delivering Community-Based Primary Care in a Universal Health System. N Engl J Med. 2015; 372(23): 2177-81. 